DOI 10.18551/rjoas.2021-09.17

\title{
SUCCESSION PATTERN OF INSECT OF FORENSIC IMPORTANCE ON RABBIT CARRION AT THREE LOCATIONS IN FEDERAL COLLEGE OF FORESTRY OF JOS, PLATEAU STATE, NIGERIA
}

\author{
Oladejo A.O. *, Musa I., Sikiru G.K., John W.C., Olori-Oke O.O., Olorundare O.O.
}

Department of Pest Management Technology, Federal College of Forestry, Jos, Nigeria

Mudi A.

Department of Crop Production Technology, Federal College of Forestry, Jos, Nigeria

Adedire 0.

Department of Statistics, Federal College of Forestry, Jos, Nigeria

*E-mail: folabiola60s@gmail.com

\begin{abstract}
The objective of this study was to identify insects species visiting decomposing rabbit carrion and to establish the relationship between insects and decomposing carrion which may be of forensic importance in Jos, Plateau state Nigeria. Six rabbit weighing between $2.3 \mathrm{~kg}$ and $2.7 \mathrm{~kg}$ were killed by a sharp blow with a blunt metal object on the heads. Two each of the six rabbit were exposed to the sun, under shade and near river. The carcasses were allowed to decompose and insect were collected twice a day for the first one week and thereafter once a day up to the end of the 15 weeks. Four decomposition stages recorded were fresh, bloating, decay and post decay stages. A total of 16 insect species from 7 families and 3 orders were observed. Three Diptera families (Calliphoridae, Muscidae and Sarcophagidae) were identified from carcasses in all the locations and they were the first to be observed. Species collected included Lucilia Cuprina, Chrymosya albiceps, Chrymosya megacephala, Phormiaregina, Musca domestica and Hydrotaea sp. Three Coleopteran families (Cleridae, Silphidae and Dermestidae) were identified from all the carcasses and the observed species were Necrobia rufipes, Necrophile rufithorax and Dermestes muculatus. Hymenoptera (Formicidae) was also present throughout the period. The study shows that insects from the order Diptera (Calliphoridae and Muscidae) indicate the fresh and bloat stage, while the order Coleopteran (Dermestidae) indicate the decay and post decay stage during period of decomposition of the carcasses and could be of importance for further forensic studies since they were collected from the carcasses.
\end{abstract}

\section{KEY WORDS}

Insects' succession, rabbit carrion, forensic entomology, decomposition stages.

Forensic entomology is the study of different insects associated with carrion in order to determine the cause, place of death, and elapsed time since death occurred (Keh, 1985; Bhat et al., 2011). Forensic entomology has become synonymous with medico-legal entomology and it involves the use of insects in legal and criminal investigations. The sequence of insect colonization of a body is predictable and can be studied from controlled experiment (Byrd and Castner, 2010). However, the discipline also encompasses legal matters associated with stored products and urban entomology, which are the two other areas of entomology that deal with the conflict between insects and humans (Byrd and Castner 2001, Hall 2001). The pathologist can only provide a reasonably accurate determination of the time of death within the first 72 hours after death, beyond this time, there is less medical information with which to correlate post mortem interval (PMI) but forensic entomologist can provide a measure of the possible post mortem interval, based upon the life cycle stages of particular fly species recovered from the corpse, or from the succession of insects present on the body. This estimate can be given over a period of hours, weeks or years (Dorothy, 2007). The start of the post mortem interval is considered to coincide with 
the point when the fly first laid its eggs on the body, and its end to be the discovery of the body and the recognition of life stage of the oldest colonizing species infesting it. The duration of this stage, in relation to the particular stage of decay, gives an accurate measure of the probable length of time the person has been dead and may be the best estimate that is available. The insects that can assist in forensic entomological investigations include blowflies, flesh flies, cheese skippers, hide and skin beetles, rove beetles and clown beetles. In some of these families only the juvenile stages are carrion feeders and consume a dead body. In others both the juvenile stages and the adults will eat the body (are necrophages). Yet other families of insects are attracted to the body solely because they feed on the necrophagous insects that are present. The first jail time sentence for wildlife poaching in Manitoba, Canada was awarded after insect evidence was used to create a timeline for the crime (Anderson 1999). Carcass-feeding (necrophagous) insects utilize decaying animals, including humans, so readily that they often arrive at a carcass before other animals (especially humans) detect them.

The presence of carrion-attending insects at carcasses, combined with their decomposition dependent life cycles, ties them to carcasses and their presence or absence can be used as evidence in investigations into death. It is evident that various insect species were attracted by animals and human carrion; these play an important role in the decomposition process (Anderson and Crevenka, 2001). However, insect associated with carrion and their times of colonization vary according to geographic zone, habitat, meteorological conditions and type of available insects (Anderson, 2010). The pattern of succession is similar to resource succession patterns observed elsewhere in nature. The first groups of insects to arrive and colonize the carcass were most often made up of Calliphorid and Sarcophagid flies (Diptera) and their larvae (maggots) that feed on the soft tissues. After the flies colonize the carcass, predators of the maggots arrive and acquire the nutrients secured by the maggots. As other tissues become exposed or accessible in the decomposition process, additional waves of insects arrive and colonize the carcass (Fazil, 2017). Given enough time and adequate temperature, insects can consume the entire carcass, leaving only the bones.

Documentation and manipulation of insect faunal succession has allowed entomologists to establish timelines for succession patterns (Watson 2003, 2005). The insects found on a carcass can be used in concert with environmental factors to estimate the minimum time since insect colonization occurred (Byrd and Castner, 2001). A formula has been proposed by forensic pathologists to estimate the time of body decomposition to a skeleton, in relation to temperature (Vass, 2001).

The formula is: $Y=1285 / X$. Where: $Y$ is the number of days to mummification, or skeletonization; $X$ is the average temperature for the days before the body was found (Vass et al., 1992). This process of carrion decomposition can be allocated to one of 4 or 5 recognizable post mortem conditions (Yan-Wei, et al., 2009; Alafia et al., 2014 and Nyasha et al., 2014). However, there is no obvious distinction from one stage to the next (Gaudry, 2002). These stages include; fresh, bloating or putrefaction, active decay, post decay and or skeletonization. Every stage is attracted to different species and offers an ideal habitat for some species so that they could lay eggs and feed \{Dorothy (2007); Fazil (2017).

In most developing Countries (Nigeria inclusive), forensic entomology has not been fully incorporated into death investigations, despite numerous homicide and poaching cases being reported almost on a daily basis. The objective of this study is therefore to identify insects' species visiting decomposing rabbit carrion and to establish the relationship between insects and decomposing carrion which may be of forensic importance in Jos, Plateau state of Nigeria.

\section{MATERIALS AND METHODS OF RESEARCH}

The study was conducted at three locations (open field, under shade, and near a stream) within the campus of Federal College of Forestry, Jos Plateau state, Nigeria. The College lies around latitude $9^{0} 51^{\prime}$ to $9057^{\prime} \mathrm{N}$ and longitude $8^{0} 53^{\prime}$ to $8^{\circ} 54^{\prime} \mathrm{E}$ in the Northern Guinea Savannah zone of Nigeria with a height of about $1200 \mathrm{~m}$ above the sea level. The 
mean annual rainfall for the location ranges between $12000 \mathrm{~cm}$ and $1250 \mathrm{~m}$ and the mean temperature of $23^{\circ} \mathrm{C}-25^{\circ} \mathrm{C}$ as obtained from University of Jos Metrological station (2013).

Test Animal Carcasses. Six rabbit (Oryctolagus cuniculus L.) of about 6 months old were bought from the animal house, Federal College of Forestry, Jos, each weighing between $2.3 \mathrm{~kg}$ and $2.7 \mathrm{~kg}$. The rabbit were killed by sharp blows with a blunt metal object on the head and placed in three locations within the College compound. At location 1; the carcass was exposed to the sun in open field while in location 2; the carcass was placed under shade and in location 3; the carcass was placed near stream. Two carcasses were used in each location and placed about $30 \mathrm{~m}$ from each other. Wire cage measuring (140x100x20)mm were placed over the carcasses to prevent them from disturbances by the vertebrate scavenger and birds, at the same time allowing the entrance of carrion insects (Wolff et al., 2001). A thermometer and hydrometer were held in the cage of each carcass $5 \mathrm{~cm}$ above the ground to record the daily ambient temperature and relative humidity.

Sample Collection. Insect samples were collected twice a day (9.00 am and $13.00 \mathrm{pm})$ for the first week and thereafter once a day till the end of 15 weeks. Sampling started on 18th December, 2019 and ended 8th April, 2020. Active flying insects such as blow flies, flesh flies and house flies were collected by hand net while the crawling insects and beetles were collected using pit fall. Larvae and pupae were collected with the help of forceps and were reared to adult in the laboratory under $250 \mathrm{C}$ and $75 \% \mathrm{RH}$ conditions. All insects were kept in plastic container containing $70 \%$ ethanol for identification.

Insect Identification. All insects collected were identified with the help of available literature using dichotomous keys \{Almeida and Mise (2009), Whitworth (2010); Akbarzadeh et al. (2015)\}, in entomology laboratory, Federal College of Forestry Jos.

Data Analysis. Alpha taxa diversity was calculated using relative abundance and dominant, Shannon-wiener index, Species evenness and species richness to compare the three (3) locations. Species diversity was estimated using Shannon-wiener diversity index as cited by Begon et al., (2003).

The relative abundance (RA) of insects was computed using the formula below according to the method of Rahaman et al., (2014) as cited by Okrikata and Ogunwolu, (2017).

$$
\text { The relative abundance }(\mathrm{RA})=\frac{\text { Total no.of individuals of each species /order }}{\text { Total no.of individuals of species /orders }} X 100
$$

Those with $\mathrm{RA}<1 \%$ will be regarded as rear/scarce species while those with $\mathrm{RA} \geq 1 \%$ were regarded as abundant/dominant species (Adja et al., 2016).

Shannon-Wiener diversity index was calculated using the equation stated below:

$$
\mathrm{H} !=-\sum_{\mathrm{i}=1}\left(P_{\mathrm{i}}\right)(\mathrm{In} P \mathrm{i})
$$

Where: $H !=$ Shannon-wiener species diversity index; $P i=$ the proportion of individuals or the abundance of the th species expressed as a proportion of the total abundance. The use of natural logs is usual because this gives information in binary digit.

Pielou's species evenness was calculated with the equation below:

$$
J !=\frac{H !(\text { Observed) }}{H \max }
$$

Where: $J !=$ Pielou's evenness index, $H !($ Observed) $/ H \max$, where $H$ max is the maximum possible diversity (Pielou, 1975 as cited by Magurran, 2004)\}.

\section{RESULTS OF STUDY}

Climatological data. There were variations in climatological data (temperature and relative humidity). At sun exposed location, the mean temperature was $31 \pm 4.00^{\circ} \mathrm{C}$, under shade was $27 \pm 3.00^{\circ} \mathrm{C}$ while near river was $25 \pm 3.00^{\circ} \mathrm{C}$ relative humidity at sun exposed 
carcasses $(73.46 \pm 1.45 \%)$ was significantly higher $(\mathrm{P}<0.05)$ when compared with under shade $(71.37 \pm 2.76 \%)$ and near river $(21.46 \pm 2.08 \%)$.

Decomposition Stages. At the end of this study, four stages of decomposition processes was observed namely: fresh, bloated, decay and post-decay following Yan-Wei, et al. (2009) and Nyasha et al. (2014). Each stage was observed in the physical process of decomposition (Tables 2). Three insect orders (Diptera, Coleoptera and Hymenoptera) were identified in association with the carrion during decomposition in all the three locations. The fresh stage began immediately after the animal died and lasted for two days. This was followed by bloating on day 3 and reach advance stage in day 4, during this period the carcasses began to smell with very strong odour. This could be as a result of breakdown of tissues by bacteria which releases gases such as hydrogen sulphide, sulphur dioxide, carbon dioxide, methane, ammonia, hydrogen and carbon dioxide (Putrefaction). Alongside this, anaerobic fermentation takes place when the volatiles propionic and butyric acid are formed. The odour was more pronounced on the sun exposed carcasses than any other locations (Dorothy, 2007; Vass et al., 2004). The carrion began to decay with sun exposed carrion first ruptured in day 5 while the carcasses under shade and near river were partially ruptured. However, full carrion ruptured takes place in day 6 and 7 respectively. By day 13, the carrion in all the locations entered the last stage with signs of dryness in all the carcasses.

Insect succession, abundance and composition. There were three insect orders that were identified in association with rabbit carrion in all the locations and they all occurred in abundance (Fig 1), they include; Diptera, Coleopera and Hymenoptera. Dipteran families identified consist of Calliphoridae, Muscidae and Sarcophagidae. Coleopteran families consist of Cleridae, Silphidae and Dermestidae, while Hymenoptera has one family Formicidae. Calliphorids and Muscids were the early colonizer arriving at the carcasses during fresh stage, ovipositing on the carcasses; all these taxa were classified as abundance $(R A \geq 1)$. However, Musca domestica are the most abundance (34.3\%) followed by Dermestids (24.7\%) then Formicidae (20.7\%) in all the locations. The family Dermestidae and Formicidae were observed from fresh stage up to decay stage in sun exposed and under shade, while near river, it was observed only in decay stages (Fig.1). Calliphorids were observed from the fresh stage up to the decay stage. On Day 7 maggot of flies were observed moving away from the carcasses and between Day 6 and Day 13, immature Calliphoride were observed in all the carcasses. The species observed were Lucilia cuprina, Chrysomya. albiceps, Chrysomya. megacepala and Phormia. regina. Hydrotaea sp was observed only during the post decay in the sun and near river exposed carcasses, while carcasses under shade started recording Hydrotaea insects from bloat stage till decay period. Sarcophaga sp was observed during the bloat and decay stages in both sun exposed and under shade while in near river the insect was observed from the fresh stage till decay.

Beetles were the last group of insect observed in the decomposition process of this study (Table 2). They were seen during the decay and post decay stages. These beetles fall into three families namely; Cleridae, Silphidae and Dermestidae. Necrophile rufithorax (Silphidae) was the first to arrive at the sun-exposed carcass on Day 5 while Necrobia rufipes (Cleridae) came last and was collected from near river carcass during the post decay stage. Dermestes sp. was the most dominant species among the beetles from all the carcasses and they prayed on the maggots of Calliphorids species.

Ant species in the family Fomicidae (Hymenoptera) was the second insects to arrive after flies and appear throughout the decomposition process in all the locations. They were seen carrying off eggs, maggots/larvae and feeding on the carcass itself.

Cultured Flies Emergence. The family Calliphoridae began to emerge after 11 days while Sarcophagidae started to emerge after 15 days of the experiment. Dermestes maculatus were only observed during the larva stage on day 30.

Insect Species Diversity, Evenness and Richness. The result showed no significant difference $(P>0.05)$ in insect diversity among the locations. However carrion placed near river has the highest diversity value across the decomposition stages, followed by sun exposed carrion (Tables $3 \& 4$ ). Decay stages recorded the highest diversity values (sun-exposed $\mathrm{H}^{\prime}=$ 
1.80; under shade $H^{\prime}=1.65$ and near river $H^{\prime}=1.89$ ) while bloat stage had the least (sun exposed $\mathrm{H}^{\prime}=1.26$; under shade $\mathrm{H}^{\prime}=0.77$ and near river $\mathrm{H}^{\prime}=1.37$ ).

It was also showed that species were better evenly distributed in sun exposed and near river locations than in under shade. Analysis of variance (ANOVA) on evenness showed carrion exposed to sun and the one under shade has no significant difference however, there was significant difference between carrion exposed to sun and the one near river (Table 3 \& 4). Species richness of insect community on rabbit carrion showed no significant difference but it was generally high in all the locations and the order of richness at the different stages of decomposition are: decay stage $>$ bloated stage $>$ fresh stage $>$ post-decay stage (Table 3).

Table 2 - Taxa Succession and abundance in four stages from rabbit carrion exposed under sun, under shade and near river

\begin{tabular}{|c|c|c|c|c|c|c|c|c|c|c|c|c|c|c|c|c|}
\hline \multirow[t]{3}{*}{ Order } & \multirow[t]{3}{*}{ Family Taxa / } & \multirow[t]{3}{*}{ Species } & \multicolumn{12}{|c|}{ RABIT CARRION } & \multirow[t]{3}{*}{$\mathrm{GT}$} & \multirow[t]{3}{*}{$A B$} \\
\hline & & & \multicolumn{4}{|c|}{ Sun-exposed } & \multicolumn{4}{|c|}{ Under shade } & \multicolumn{4}{|c|}{ Near river } & & \\
\hline & & & $\mathrm{FS}$ & BS & DS & PDS & FS & $\mathrm{BS}$ & DS & PDS & FS & $\mathrm{BS}$ & DS & PDS & & \\
\hline \multirow[t]{6}{*}{ Diptera } & Calliphoridae & Lucilia cuprina & 5 & 3 & 7 & - & 2 & 8 & 2 & - & 4 & $\overline{9}$ & 11 & - & 51 & 3.7 \\
\hline & & Chrysomya albbcep & 2 & 5 & 9 & - & 2 & 12 & 3 & - & 2 & 4 & 6 & - & 45 & 3.3 \\
\hline & & $\begin{array}{l}\text { Chrysomya } \\
\text { megacepala }\end{array}$ & 2 & 3 & 8 & - & 5 & 3 & 1 & - & 3 & 5 & 7 & - & 37 & 2.7 \\
\hline & & Phormia regina & 1 & 2 & 2 & - & 4 & 4 & 1 & - & 2 & 1 & 3 & - & 20 & 1.5 \\
\hline & Muscidae & Musca domestica & 3 & 47 & 55 & - & 2 & 205 & 50 & - & - & - & 42 & 63 & 467 & 34 \\
\hline & & Hydrotaea Spp & - & - & . & 6 & - & 2 & 1 & - & - & - & . & 10 & 19 & 1.4 \\
\hline \multirow[t]{4}{*}{ Coleoptera } & Sarcophagidae & Sarcophagae Spp & - & 2 & 1 & 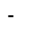 & - & 4 & 5 & - & 1 & 3 & 5 & - & 21 & 1.5 \\
\hline & Cleridae & Necrobia rufipes & - & - & 4 & 9 & - & - & 3 & 9 & - & - & - & 9 & 34 & 2.5 \\
\hline & Silphidae & $\begin{array}{l}\text { Necrophile } \\
\text { rufithorax }\end{array}$ & - & - & 8 & 10 & - & - & 6 & 7 & - & - & 8 & 10 & 49 & 3.6 \\
\hline & Dermestidae & $\begin{array}{l}\text { Dermestes } \\
\text { muculatus }\end{array}$ & - & - & 15 & 70 & - & - & 30 & 122 & - & - & 22 & 78 & 337 & 25 \\
\hline Hymenoptera & $\begin{array}{l}\text { Formicidae } \\
\text { Total }\end{array}$ & Formicidae Spp & $\begin{array}{l}21 \\
34\end{array}$ & $\begin{array}{l}28 \\
90\end{array}$ & $\begin{array}{l}18 \\
127\end{array}$ & $\begin{array}{l}32 \\
127\end{array}$ & $\begin{array}{l}25 \\
40\end{array}$ & $\begin{array}{l}10 \\
248\end{array}$ & $\begin{array}{l}20 \\
122\end{array}$ & $\begin{array}{l}40 \\
178\end{array}$ & $\begin{array}{l}15 \\
27\end{array}$ & $\begin{array}{l}24 \\
46\end{array}$ & $\begin{array}{l}18 \\
122\end{array}$ & $\begin{array}{l}31 \\
201\end{array}$ & $\begin{array}{l}282 \\
1362\end{array}$ & $\begin{array}{l}21 \\
100\end{array}$ \\
\hline
\end{tabular}

Note: FS = Fresh Stage; BS = Bloated Stage; DS = Decay Stage; $P$-DS = Post-decay Stage; Spp = Species; $\mathrm{NI}=$ Not Identified; $\%$ = Percentage $; A B=$ Abundance .

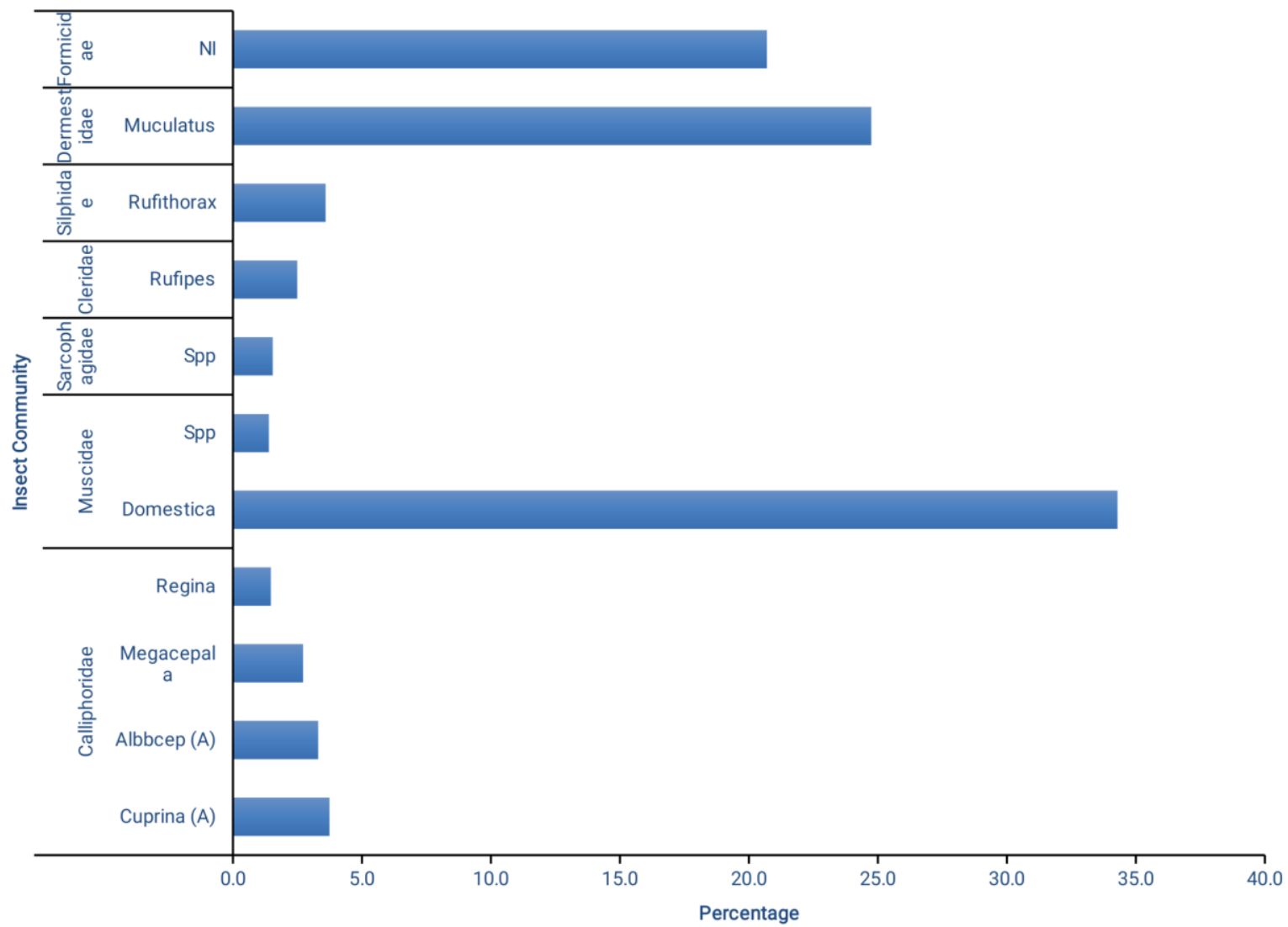

Figure 1 - Composition and Abundance of insect community 
Table 3 - Summary Characteristics of insect community from rabbit carrion during decomposition stage

\begin{tabular}{lllllllllllll}
\hline & \multicolumn{3}{l}{ Fresh Stage } & \multicolumn{3}{c}{ Bloated Stage } & \multicolumn{3}{c}{ Decay Stage } & \multicolumn{3}{c}{ Post-decay Stage } \\
\cline { 2 - 12 } & $\mathrm{H}^{\prime}$ & $\mathrm{J}^{\prime}$ & $\mathrm{D}$ & $\mathrm{H}^{\prime}$ & $\mathrm{J}^{\prime}$ & $\mathrm{D}$ & $\mathrm{H}^{\prime}$ & $\mathrm{J}^{\prime}$ & $\mathrm{D}$ & $\mathrm{H}^{\prime}$ & $\mathrm{J}^{\prime}$ & $\mathrm{D}$ \\
\hline Sun-Exposed & 1.23 & 0.69 & 6 & 1.26 & 0.65 & 7 & 1.80 & 0.78 & 10 & 1.21 & 0.75 & 5 \\
Under Shade & 1.23 & 0.69 & 6 & 0.77 & 0.37 & 8 & 1.65 & 0.69 & 11 & 0.87 & 0.63 & 4 \\
Near River & 1.36 & 0.76 & 6 & 1.37 & 0.77 & 6 & 1.89 & 0.86 & 9 & 1.46 & 0.81 & 6 \\
\hline
\end{tabular}

Note: $H^{\prime}=$ Shannon-wiener diversity index; $J^{\prime}=$ Evenness Index (\%); $D=$ Species Richness.

Table 4 - Diversity index of insect community from rabbit carrion during decomposition stage $($ mean $\pm \mathrm{SE})$

\begin{tabular}{llll}
\hline & Sun-exposed & Under shade & Near river \\
\hline Diversity $H^{\prime}$ & $1.38^{\mathrm{a}} \pm 0.16$ & $1.13^{\mathrm{a}} \pm 0.16$ & $1.52^{\mathrm{a}} \pm 0.16$ \\
Evenness $J^{\prime}$ & $0.72^{\mathrm{ab}} \pm 0.05$ & $0.60^{\mathrm{b}} \pm 0.05$ & $0.80^{\mathrm{a}}{ }^{\mathrm{a}} \pm 0.05$ \\
Richness $D$ & $7.00^{\mathrm{a}} \pm 1.15$ & $7.25^{\mathrm{a}} \pm 1.15$ & $6.75^{\mathrm{a}} \pm 1.15$ \\
\hline
\end{tabular}

Means on the same column with the same letter superscript do not differ significantly from each other $(P=0.05)$.

\section{DISCUSSION OF RESULTS}

Insect growth is regulated by temperature and food availability. Decomposition rate (food) is also affected by changes in temperature and humidity (Lopes de Carvalho and Linhares, 2001; Kočárek, 2003). Insect succession on decomposing carrion is a more reliable indicator of post mortem than traditional methods utilized by medical examiners. Immediately after the death, the early insect species that colonized the carrion are those from three families: Calliphoridae, Muscidae and Sarcophagidae (Grassberger and Frank, 2004; Goddard et al., 2012). This was confirmed in this study as the Calliphoridae and Muscidae were the first to arrive at all the locations when the carcasses were soft and produced exudates (autolysis) as a result of natural breakdown of cells by digestive enzymes for the flies to feed on. This process can be most rapid in organs such as the brain and liver (Vass, 2001).

Generally, decomposition process followed the same trend viz-a-vis insect succession in all the locations. Notwithstanding, there might be some variation on the duration of one stage to another because there is no obvious distinction from one stage to the next (Gaudry, 2002). In this study, Deflation of the swollen abdomen and exposure of internal organ signal the onset of active decomposition and this occurred in sun exposed carrion on the $5^{\text {th }}$ day which was one or two days earlier than the carcasses under shade and near river respectively. This finding is line with the work done by Okiwelu et al. (2008), who observed faster decomposition in carcasses exposed to sun than those in shade or cooler areas. Maggots were observed from the fifth day in sun exposed carrion and on day 6 and 7 in under shade and near river respectively. This observation is contrary to the findings of Dupont et al. (2011) and Castrol et al. (2012) who observed maggots from rats and piglet carrions on the second and eight days of decomposition respectively. This could probably be attribute to the differences in carrion sizes; that is 'the bigger the longer the emergence of maggot from the carrion'. The body undergoes active decay, in which protein sources are broken down into fatty acids by bacteria (Vass, 2001).

During the post decay stage of decomposition, the carcasses were showing signs of dryness. Hence the number of flies visiting the carcasses began to decrease except on carcasses near river(table 2). Beetles (Coleopteran) recorded are Cleridae, Silphidae and Dermestidae. Dermestes sp. was the dominant species being collected from the decay stage from the sun exposed carcass. However other studies have collected this species as early as boat stage (VanLaerhoven \& Anderson, 1999). Species diversity rose to its peak with increase abundance of coleopteran species, the species collected were; Necrobia rufipes, Necrophile rufithorax and Dermestes maculates in all the locations, (table 2). This confirms the work of Alafia et al. (2017), and VanLaerhoven \& Anderson (1999) who attached the presence of these beetles to the peak of their seasonal appearance. 
The family Fomicidae (Hymenoptera) was the second insects to arrive after flies and appear throughout the decomposition process in all the locations. It was observed that they fed on the carcass which is in contact to the soil and emerged maggots. This confirmed the observation made by Morreti et al. (2013), as a result they were categorized as an important component of the Sarcophagidae community. When the soft tissue is removed, skeletal material - organic and inorganic remains are further broken down by environmental conditions and are finally reduced to components of the soil.

\section{CONCLUSION}

The result of this study indicates that weather parameters determine carrion decomposition, insect development rate and succession. The decomposition process and insect succession followed the same trend in all the locations. However, there might be some variation on the duration of one stage to another because there is no obvious distinction from one stage to the next. The information obtained from this study could be useful for initial data base; still there is need for repeat and replicate of this study at different locations and different time of the year, so as to provide multiple sets of baseline succession data for Nigerian and for future studies.

\section{REFERENCES}

1. Adja, N.A.; Danho, M.; Alabi, T.A.F.; Zimmer, J.Y.; Francis, F.; Gnago, A.J.; Konassi, K.P.; Zoro, I.A. and Baudoin, J.P. (2016). Identification and Impact of Insects feeding on the stored seeds of Lagenaria siceravia Molina (Standl, 1930) and Citrullus lanatus Thunb (Matsum \& Nakai). American Journal of Research Communication. www.usajournals.com. Vol. 4(2), 104-132.

2. Alafia, A.O.; Anikwe, J.C. and Makanjuola, W.A. (2017). Succession Partan insects of forensic importance on Pig (Sus scrofa Linn) carrion in Lagos and Kaduna States of Nigeria. Nigerian Journal of Entomology Vol. 33. pp. 23-36

3. Akbarzadeth, K.; Wallman, J.F.; Sulakova, H. and Szpila, K. (2015). Species identification of Middle Eastern blowflies (Dipptera; Calliphoridae) of forensic importance. Parasitol Res 114(4).1463-1472.

4. Almeida, L.M.and Mise, K.M. (2009). Diagnosis and key of the main families and species of South American coleopteran of forensic importance Revista Brasileria de Entomologia 53(2), 227-244.

5. Anderson, G.S. (1999) 'Wildlife forensic entomology: Determining time of death in two illegally killed black bear cubs.' Journal of Forensic Sciences, vol. 44(4). pp. 856 -859.

6. Anderson, G.S.(2000) 'Minimum and maximum development rates in some forensically important Calliphoridae (Diptera).'Journal of Forensic Sciences, vol. 45(4), pp.824-832.

7. Anderson, G.S. (2010). Factors that influence insect succession on carrion. In: Byrd JH, Castner JI, editiors. Forensic entomology: the utility of arthropods in legal investigations. 2nd ed. Boca Raton FL: CRC Press p201-250.

8. Anderson, G.S. and Cervenka, V.J. (2001). Insect associated with the body; their use and analysis In; haglund and sorg (Eds). Forensic Taphonomy. The postmortem Fate of Human Remain. Boca Raton CRC press.

9. Begon, M.; Harper, J.L. and Townsend, C.R. (2003). Ecology of Individuals Populations and Communities (4th edition) Blackwell Science Ltd. 884-912.

10. Bhat, M.A.; Shrivastav, A.B.; Qurereshi, S.R. and Quadri, S.A. (2011). Foresic exploitation of veterinary entomology. International Journal of Agro-Veterinary Medical Sciences. 5(4): 429-437.

11. Byrd, J.H., and Castner, J.L. (2001). Forensic entomology: The Utility of arthropods in legal investigations. CRC press, Boca Raton, FL.30.

12. Byrd, J.H. and Castner, J.L. (2010). 'Forensic entomology: The utility of arthropods in legal investigations.' 2nd edition_CRC Press. New York. 
13. Castrol, C.P.; Serrano, A.; Marins,D.A.; Silva, P. and Garcia, M.D. (2012). Carrion flies of forensic interest: a study of seasonal community composition and succession in Libson, Portugal. Med Vet Entomol 26(4): 417-431.

14. Dorothy, E.G. (2007). Forensic entomology an introduction. John Wiley \& Sons Ltd. The Atrium, Southern Gate, Chichester, West Sussex PO19 8SQ, England. British Library Cataloguing in Publication Data ISBN 978-0-470-01478-3 (HB) 9780470-01479-0 (PR). www. wiley.com

15. Dupont, F.Y.; Champlain, D.L.; Cyrille, A.A. and Felix, B.B. (2011). A prelimnary study of arthropod associated with carrion in Yaounde, Cameroon: a first step in forensic entomology in Central Africa. Journal of Ecology Natural Environment. 3(6); 215-220.

16. Fazil, Amin (2017). Insect succession on Rabbit (Oryctolagus Cuniculus) carrion in District Peshawar, International Journal of Bioscience IJB ISSN 2220-6655, www.innspub.net. vol.10, No 6, pp. 253-258.

17. Gaudry, E. (2002). Eight squadrons for one target: the fauna of cadaver described by P. Mégnin. Proceedings of the First European Forensic Entomology Seminar, 77 eafe.org/OISIN; $\mathrm{p} 23$.

18. Goddard, J.; Fleming, D.J.; Seltzer, J.I.; Anderson, S.; Chesnut, C. and Cook, M. (2012). Insect succession on pig carrion in North-Central Mississippi.Mid-south entomologist.5: 39-53.

19. Grassberger, M. and Frank, C. (2004). Initial study of arthropod succession on pig carrion in a central European urban habitat. Journal of Medical Entomology. 41: 511-523.

20. Hall, R.D.(2001). Introduction: Perceptions and Status of Forensic Entomology. In forensic entomology. In J.H. Byrd and J.L. castner (eds), forensic entomology. The utility of arthropods in legal Investigations. CRC press, Boca Raton, FL.

21. Keh, B. (1985). Scope and Application of Forensic Entomology. Annual Review of Entomology, 30, 137-154

22. Kocarek, P. (2003). Decomposition and coleopteran succession on exposed carrion of small mammal in opava the Czech Republic: European Journal of Soil Biology, vol. 39(1), pp.32-45.

23. Lopes de Carvalho, L.M. and Linhares, A.X. (2001). Seasonality of insect succession and pig carcass decomposition in a natural forest area in south eastern Brazil. Journal of Forensic Science, 46, 604-608.

24. Magurran A.E. (2004). Measuring biology diversity. Blackwell Publishing Company, Oxford, ISBN 063205633.9. http://www.blackwellpublishing.com.

25. Morreti, T.; Solis D.R. and Godoy, W.A. (2013). Ants (Hymenoptera: Formicidae) collected with carrion-baited traps in Southeast Brazil. Open Forensic Science Journal. 7:1-5.

26. Nyasha, Mabika; Ron, Masendu and Gilbert, Mawera (2014). An initial study of insect succession on decomposing rabbit carrions in Harare, Zimbabwe. Asian Pacific Journal of Tropical Biomedicine. 4(7): 561-565.

27. Okiwelu, S.N.; Ikpamii, T. and Umeozor, O.C. (2008). Arthropod associated with mammalian carcasses in River State, Nigeria. African Journal of Biomedical Research. 11: 339-342.

28. Okrikata, E. and Ogunwolu, E.O. (2017). Farmers' Perceptons on Arthropod pests of Watermelon and their Management Practices in the Nigerian Southern Guinea Savanna. International Journal of Agricultural Research (ijar). ISSN 1816-4897.

29. University of Jos Metrological Station (2013). Metrological Station Geography and Planning Department, Faculty of Environmental Science University of Jos, Jos Nigeria.

30. VanLaerhoven, S.L. and Anderson, G.S. (1999). Insect succession on buried carrion in two biogeoclimatic zones of Britist Columbia. Journal of Forensic Sciences, 44, 32-43.

31. Vass, A.A. (2001). Beyond the grave - understanding human decomposition. Microbiology Today 28: 190-192.

32. Vass, A.A.; Bass, W.B.; Wolt, J.D.; Foss, J. E. and Ammons, J. T. (1992). Time since death determinations of human cadavers using soil solution. Journal of Forensic Sciences 37(5): 1236-1253. 
33. Vass, A.A.; Smith, R.R.; Thompson, C.V.; Burnett, M.N. (2004). Decompositional odour analysis database. Journal of Forensic Sciences 49(4): 1-10.

34. Watson, E. J. and Carlton, C.E. (2003). Spring Succession of Necrophilous Insects on Wildlife Carcasses in Louisiana. Journal of Medical Entomology 40: 10.

35. Watson, E. J. and Carlton, C.E. (2005). Insect Succession and Decomposition of Wildlife Carcasses During Fall and Winter in Louisiana. Journal of Medical Entomology 42: 11.

36. Whitworth, T. (2010). Keys to the genera and species of blow flies (Diptera: Calliphoridae) of the West Indies and description of a new species Lucilia RobineauDesvoidy, Zootaxa. 2663:1-35.

37. Wolff M,Uribe A,Ortiz A,Duque P. 2001 A preliminary study of forensic entomology in Medellin Colombia science international 120,53-59.

38. Yan-Wei, Shi; Xiao-Shan, Liu; Hai-Yang, Wang and Run-Jie, Zhang (2009). Seasonality of insect succession on exposed rabbit carrion in Guangzhoi, China. Journal compilation, Institute of Zoology, Chines Academic of Sciences. 